\title{
Pharmacognostic and Antibacterial Effect of Citrullus lanatus Leaves against Selected Respiratory Tract Pathogens
}

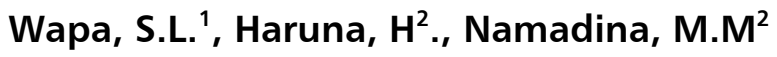 \\ ${ }^{1}$ Department of Biological Science, \\ Federal University \\ Dutsinma \\ ${ }^{2}$ Department of Plant Biology, \\ Bayero University \\ Kano
}

\begin{abstract}
Bacterial species have been reported to develop resistance to antibiotics commonly prescribed for respiratory tract infections. Therefore, the need to search for natural products for the remedy of this problem cannot be overemphasized. The extraction of Citrullus lanatus leaves was carried out using cold maceration extraction method. Chemomicroscopical and phytochemical analysis were carried out using the standard methods. Agar well diffusion, agar dilution and spread plate methods were employed to determine the zone of inhibition, minimum inhibitory concentration, minimum bactericidal concentration and rate of kill respectively. Chemomicroscopical evaluation revealed the presence of cellulose, tannins, starch, lignin, calcium oxalate, suberin, aleurone grain and mucilage with the exception of calcium carbonate. Phytochemical screening of Citrullus lanatus revealed the presence of phenolic compounds and flavonoid as secondary metabolites. The antibacterial activity result indicated that $S$. aureus showed higher zone of inhibition $(20 \mathrm{~mm}$ and $24 \mathrm{~mm}$ ) followed by $\mathrm{K}$. pneumoniae $(18 \mathrm{~mm}$ and $22 \mathrm{~mm})$ and P. aeruginosa $(18 \mathrm{~mm}$ and $20 \mathrm{~mm})$ at a concentration of 250 $\mathrm{mg} / \mathrm{ml}$ in aqueous and methanol extract respectively. The two extracts showed broad spectrum of activity and moderate M.I.C and M.B.C values ranging from $15.625 \mathrm{mg} / \mathrm{ml}-31.25 \mathrm{mg} / \mathrm{ml}$ respectively. $L D_{50}$ of both extracts was above $5000 \mathrm{mg} / \mathrm{kg}$ and did not cause mortality in all the tested rats. The results of this investigation may be useful for deriving doses that are safe for human consumption medicinally.. This study has justified the traditional use of Citrullus lanatus leaf extract in the treatment of respiratory tract infection caused by bacteria.
\end{abstract}

Keywords: Agar well diffusion, Chemomicroscopical, Minimum inhibitory concentration, Minimum bactericidal concentration, phytochemical, Citrullus lanatus

\section{INTRODUCTION}

Antimicrobial drug resistance is a global challenge for the 21st century with the emergence of resistant bacteria strains worldwide (Furin et al., 2011). Respiratory tract infections impose a serious economic burden on society, ranging from reduced output in workplaces to frequent prescription by physicians of antibiotics, even when the causative agents of 
infection is not bacteria (Jafari et al., 2009). Respiratory tract infections are amongst the most wide spread and serious infection, accounting for over 50 million deaths globally each year (Zafar et al., 20008). In 2012, lower respiratory infections such as pneumonia and bronchitis were the second causes of mortality and morbidity in Sub-Saharan Africa, accounting for over 1 million or $11.5 \%$ of deaths in the region, while tuberculosis accounted for $2.4 \%$ (Siikamaki, 2015). Acute respiratory tract infection is a common cause of hospital admission in Nigeria, as it was estimated that pneumonia accounted for $20 \%$ of death in children under age of 5 years (Akanbi et al., 2009). The increasing prevalence of multi-drug resistant strains of bacteria and the recent appearance of strains with reduced susceptibility to antibiotics raised the spectre of untreatable bacterial infections and adds urgency to the search for new infection-fighting strategies (Rojas et al., 2006).

Medicinal properties of plants are hinged on the presence of bioactive principles such as alkaloids, phenols, tannins, glycosides and essential oils among others. This necessitates the continued screening of medicinal plants, not only to determine the scientific basis for their usage, but also to discover possible new active principles (Karou et al., 2006). The primary benefits of using plant derived medicines are that they are relatively cheaper than synthetic alternatives, offering profound therapeutic benefits and more affordable treatments. Many of the plant materials used in traditional medicine are readily available in rural areas and this has made traditional system of medicine relatively cheaper than modern medicine. Many works have been carried out with the aim of knowing the different antimicrobial and phytochemical constituents of medicinal plants and using them for the treatment of microbial infections as possible alternatives to antibiotics and other chemotherapeutic agents to which many infectious microorganisms have become resistant.

Water melon plant (Citrullus lanatus) is a prostrate or climbing annual plant with several herbaceous, rather firm and stout stems up to $3 \mathrm{~m}$ long; the young parts are densely woolly with yellowish to brownish hairs while the older parts become hairless (Erhirhe and Ekene, 2013). For centuries, Citrullus lanatus has been reportedly used widely in traditional herbal medicine for treatment of various health alignments (Deshmukh et al., 2015). It has been used as anthelmintic, anticancer, antibacterial, demulcent and a diuretic being used in the treatment of dropsy and renal stones. The aim of this research is to evaluate the antibacterial activity of different extracts of Citrullus lanatus leaf against some bacterial isolates associated with respiratory tract infections.

\section{MATERIALS AND METHODS}

\section{Collection and Identification of Plant Materials}

The leaves of Citrullus lanatus were collected from a local farm at Katsina Local Government Area of Katsina State, Nigeria. The plant was identified and authenticated in the herbarium of the Plant Biology Department of Bayero University, Kano, Kano State, Nigeria and a voucher specimen number was deposited.

\section{Preparation of Plant extracts}

The leaves of the plant was cleaned, air dried and ground to coarse powder using a mortar and pestle. The powder was stored in air tight containers for further use. Fifty grams $(50 \mathrm{~g})$ each of the powdered leaves was soaked into $500 \mathrm{ml}$ each of hexane, ethyl acetate, methanol and distilled water. The mixtures were allowed to stand for 3 days at room temperature (28 $\pm 2^{\circ} \mathrm{C}$ ) with hourly agitations. Each extract was sieved through a muslin cloth, filtered 
through a Whatman (No.1) filter paper, poured unto a clean evaporating dish and placed on a water bath at $50^{\circ} \mathrm{C}$ until all the solvent evaporated.

\section{Chemo-microscopic Studies on the leaves of Citrullus lanatus}

Powdered leaves of Citrullus lanatus was used for this study to detect the presence of cell wall materials and cell inclusions. Finely ground sample of plant was cleared in a test tube containing $70 \%$ chloral hydrate solution. It was then be boiled on a water bath for about thirty minutes to remove obscuring materials. The cleared sample was mounted with dilute glycerol onto a microscope slide. Using various detecting reagents the presence of cell wall materials and cell inclusions were detected in accordance with WHO (2011) guidelines.

\section{Determination of Cell Wall Materials}

Test for Cellulose

A drop or two of iodinated zinc chloride was added to the powdered sample and allowed to stand for a few minutes and observed under a microscope. It stained cellulose cell wall blue to blue- violet.

Test for lignin

The powdered plant material was moistened on a slide with a small volume of phloroglucinol and allowed to stand for about two minutes or until almost dry. A drop of hydrochloric acid was added and view under a microscope. Pink stained or cherry red was observed, for the presence of lignin (WHO, 2011).

\section{Test for suberized or cuticular cell walls}

A drop or two of Sudan red was added to the cleared powdered sample and allowed to stand for a few minutes, and then observed under a microscope. Orange-red or red colour was observed for the presence of suberin or cutin on the cell.

Test for gum and mucilage

To a small portion of the cleared powdered sample of the plant, a drop of ruthenium red was added. Appearance of pink coloration was considered positive for gums and mucilage.

\section{Determination of Cell Inclusions/ Cell Contents Test for starch grains}

To a small portion of the cleared powdered sample of the plant, N/50 iodine was added. Appearance of blue-black or reddish-blue coloration on some grains would be considered positive for starch.

\section{Test for calcium oxalates and calcium carbonates}

To a small portion of the cleared powdered sample of the plant, $\mathrm{HCl}$ was added, dissolution of crystals in the powdered drug without effervescence was considered positive for calcium oxalate while slow dissolution with effervescence was considered positive for calcium carbonate.

\section{Inulin}

A drop of 1-naphthol and that of sulphuric acid was added to the powdered sample and viewed under the microscope. Spherical aggregations of crystals of inulin turned brownishred and dissolve.

\section{Test for tannins}

To a small portion of the cleared powdered sample of the plant, $5 \%$ ferric chloride solution was added. Appearance of greenish-black colour was considered as positive for tannins. 


\section{Qualitative Phytochemical Screening of Different Extracts of Citrullus lanatus Leaves}

The plant extracts were subjected to phytochemical screening in order to identify the phytochemical constituents of the plant using the methods described below.

\section{Tests for carbohydrates}

Molish's (General) Test for carbohydrates: To $1 \mathrm{ml}$ of the filtrate, $1 \mathrm{ml}$ of Molish's reagent was added in a test tube, followed by $1 \mathrm{ml}$ of concentrated sulphuric acid down the test tube to form a lower layer. A reddish colour at the interfacial ring indicates the presence of carbohydrate (Evans, 2009).

\section{Tests for saponins}

Frothing test: About $10 \mathrm{ml}$ of distilled water was added to a portion of the extract and was shaken vigorously for 30 seconds. The tube was allowed to stand in a vertical position and was observed for 30 mins. A honeycomb froth that persists for 10-15 mins indicates presence of saponins (Evans, 2009).

\section{Test for Flavonoids}

Shinoda Test: A portion of the extract was dissolved in 1-2 $\mathrm{ml}$ of $50 \%$ methanol in the presence of heated metallic magnesium chips and a few drops of concentrated hydrochloric acid were added. Appearance of red color indicates the presence of flavonoids (Evan, 2009).

\section{Test for Alkaloids}

Wagner's Test: Few drops of Wagner's reagent was added into a portion of the extract, whitish precipitate indicates the presence of alkaloids (Evans, 2009).

\section{Test for Steroids and Triterpenes}

\section{Liebermann-Burchard's test:}

Equal volumes of acetic acid anhydride was added to the portion of the extract and mixed gently. Concentrated sulphuric acid $(1 \mathrm{ml})$ was added down the side of the test tube to form a lower layer. A colour change observed immediately and later indicates the presence of steroid and triterpenes. Red, pink or purple colour indicates the presence of triterpenes while blue or blue green indicates the presence of steroids (Evans, 2009).

\section{Test for Cardiac Glycosides}

Kella-killiani's test:

A portion of the extract was dissolved in $1 \mathrm{ml}$ of glacial acetic acid containing traces of ferric chloride solution. This was then transferred into a dry test tube and $1 \mathrm{ml}$ of concentrated sulphuric acid was added down the side of the test tube to form a lower layer at the bottom. Interphase for purple-brown ring was carefully observed, this indicates the presence of deoxy sugars and pale green colour in the upper acetic acid layer indicates the presence of cardiac glycosides (Evans, 2009).

\section{Test for Tannins}

\section{Ferric chloride test:}

Exactly 3-5 drops of ferric chloride solution was added to the portion of the extract. A greenish black precipitate indicates the presence of condensed tannins while hydrolysable tannins give a blue or brownish blue precipitates (Evans, 2009). 


\section{Test for Anthraquinones}

Borntrager's test:

Exactly $5 \mathrm{ml}$ of chloroform was added to the portion of the extract in a dry test tube and shaken for at least 5 mins. This was filtered, and the filtrate shaken with equal volume of $10 \%$ ammonium solution, bright pink colour in the aqueous upper layer indicates the presence of free anthraquinones (Evans, 2009).

\section{Antibacterial Activity}

\section{Isolation of Bacterial species}

The specimens were cultured on sterile blood agar, chocolate agar and Mac-conkey agar plates at $37^{\circ} \mathrm{C}$ for $24 \mathrm{~h}$ in an incubator. Discrete colonies were picked based on their morphology and further sub-cultured on blood agar and chocolate agar to obtain pure strains. The isolated colonies were Gram stained and based on their Gram reactions were inoculated on different selective media - mannitol salt agar, cetrimide agar, eosin methylene blue agar. Different biochemical tests were conducted (catalase, coagulase, and oxidase tests). All the isolates that grew on selected agar media were then placed on nutrient agar and chocolate agar slants and maintained in a refrigerator at $4^{\circ} \mathrm{C}$ (Cheesbrough, 2006).

\section{Identification and characterization of test organism using rapid test kits}

Identification and characterization of the bacteria was carried out using Microgen Identification Kit (XYZ). The test was performed according to the manufacturer's specifications (API biomerieux). It was performed by adding saline suspension of the test organisms to each of the wells, and appropriate wells (1, 2, 3 and 9) were overlaid with sterile paraffin oil. After overnight incubation (18-24 hours) at $37^{\circ} \mathrm{C}$, suitable reagents such as Nitrate A and B, Kovacs, Typtophan deaminase (TDA), Voges-proskauer (VPI and II) were added to wells 8,10 and 12 for additional tests and colour changes of the different tests recorded. The results were converted into four to eight digits codes depending on the organisms being tested and interpreted using the Microgen Identification Software Package (MID-60) (Sylvester, 2016).

\section{Preparation of extract concentration}

This was carried out according to the method described by Srinivasan et al. (2009). Stock solution of the plant extracts were prepared by adding $0.5 \mathrm{~g}$ of each crude plant extract in 1 $\mathrm{ml}$ dimethyl sulphuroxide (DMSO). From each of the stock solutions, $250 \mathrm{mg} / \mathrm{ml}, 125$ $\mathrm{mg} / \mathrm{ml}, 62.5 \mathrm{mg} / \mathrm{ml}$ and $31.25 \mathrm{mg} / \mathrm{ml}$ concentrations were prepared using two-fold serial dilution method (Srinivasan et al., 2009).

\section{Standardization of bacterial inoculum.}

Using inoculum loop, over-night grown agar culture (bacteria) was transferred into a test tube containing normal saline until the turbidity of the suspension matched the turbidity of the $0.5 \mathrm{McFarland}$ Standard as described by the national committee for clinical laboratory standard (NCCLS, 2008).

\section{Susceptibility test of bacterial isolates to different concentrations of the extracts}

The antibacterial activity of Citrullus lanatus crude extracts (methanol and aqueous) against Klebsiella pneumoniae, Staphylococcus aureus, Escherichia coli, Streptococcus sp. and Pseudomonas aeruginosa were evaluated using agar well diffusion method of susceptibility test (Srinivasan et. al., 2009). Mueller-Hinton agar plates were inoculated with $0.1 \mathrm{ml}$ of standardized 
inoculum of each bacterium and fungus respectively (in triplicates) using $0.1 \mathrm{ml}$ pipette and spread uniformly with sterile swab sticks. Three wells of $6 \mathrm{~mm}$ size were made with a sterile cork borer into the inoculated agar plates. Using a micropipette, $0.1 \mathrm{ml}$ volume of the various concentrations i.e. $250 \mathrm{mg} / \mathrm{ml}, 125 \mathrm{mg} / \mathrm{ml}, 62.5 \mathrm{mg} / \mathrm{ml}$ and $31.25 \mathrm{mg} / \mathrm{ml}$ each of the crude extracts were dispensed into wells of inoculated plates. DMSO was used as negative control. Commercially available standard antibiotic, ciprofloxacin and fluconazole were used as positive control parallel with the extracts. The prepared plates were then left at room temperature $\left(37^{\circ} \mathrm{C}\right)$ for 10 minutes, allowing the diffusion of the extracts into the incubation at $37^{\circ} \mathrm{C}$ for $24 \mathrm{hrs}$. in an incubator. The diameter of inhibition zones (DIZ) were measured and expressed.

\section{Determination of minimum inhibitory concentration (MIC)}

The method used was the tube dilution method (Adesokan et al., 2007). Thus, the plant extracts were serially diluted from $250 \mathrm{mg} / \mathrm{ml}$ solution to obtain varying concentration. The concentrations were $125 \mathrm{mg} / \mathrm{ml}, 62.5 \mathrm{mg} / \mathrm{ml}, 31.25 \mathrm{mg} / \mathrm{ml}$, and $15.625 \mathrm{mg} / \mathrm{ml}$. Doubling dilutions of the extract were incorporated in Muller Hinton broth (Oxoid, UK), and then inoculated with $0.1 \mathrm{ml}$ each of standardized suspension of the test organisms into the various test tube containing varying concentrations. Another set of test tubes containing only Mueller Hinton broth were used as negative control, and another test tube containing Mueller Hinton broth and test organisms were used as positive control. All the test tubes and controls were then incubated at $37^{\circ} \mathrm{C}$ for $24 \mathrm{hrs}$. After the incubation period, the presence or absence of growth on each tube was observed. A loop full from each tube was further sub-cultured onto nutrient agar to confirm whether the bacterial growth was inhibited.

\section{Determination of minimum bactericidal concentration (MBC)}

The MBC was determined by collecting $1 \mathrm{ml}$ of broth culture from the tubes used for the MIC determination and sub-culturing into fresh solid nutrient agar plates. The plates were incubated at $37^{\circ} \mathrm{C}$ for $24 \mathrm{hr}$. The least concentration that did not show any growth after incubation was regarded as the MBC (Adesokan et al., 2007).

\section{Acute Toxicity Study on Methanol Extract of Citrullus Lanatus leaves}

\section{Lethal Dose $\left(\mathrm{LD}_{50}\right)$ Determination}

The method of Lorke (1983) was employed. This was done in three phases. Phase I involved the oral administration of three different doses of 10, 100 and 1,000 mg/kg of the crude extract, to three different groups of three adult Wistar albino rats. In a fourth group, three adult male Wistar albino rats were administered an equivalent volume of distilled water to serve as control. All the animals were orally administered the extractsthrough gavage. . The animals were monitored closely every 30 minutes for the first 3 hours after administration of the crude extracts, and then hourly for the next 6 hours for any adverse effects. Then the animals were left for 72 hours for further observation.

When no death occurred, the phase II was employed, only one animal was required in each group. Groups 1-4, animals were orally given 1,500, 2,200, 3250 and 5,000 mg/ kg extract respectively . All the animals were left for observation as in stage one.

\section{RESULTS}

Chemo-microscopical examination of powdered leaves of Citrullus lanatus revealed the presence of cellulose, tannins, starch, lignin, calcium oxalate, suberin, aleurone grain and mucilage but calcium carbonate was absent (Table 1) 
Table 1. Chemomicroscopical studies of Citrullus lanatus powdered leaves

\begin{tabular}{lc}
\hline Constituents & Inference \\
\hline Starch & + \\
Gum and Mucilage & + \\
Cellulose cell walls & + \\
Lignin & + \\
Aleurone grain & + \\
Calcium oxalate crystals & - \\
Calcium carbonate & + \\
Suberized/Cuticular cell wall & + \\
\hline
\end{tabular}

Phytochemical screening of hexane, ethyl acetate, aqueous and methanol extracts revealed the presence of alkaloids, tannins, flavonoids, carbohydrate triterpenes and steroid while anthraquinones was absent (Table 2). Saponins and glycosides were absent in hexane extract but present in aqueous and methanol extracts while saponin was absent in the ethyl acetate fraction.

Table 2. Qualitative phytochemical screening of different extracts of Citrullus lanatus leaves

\begin{tabular}{lcccc}
\hline Metabolites & \multicolumn{3}{c}{ Inferences } & \\
\cline { 2 - 5 } Alkaloid & Hexane & Ethyl acetate & Methanol & Aqueous \\
Flavonoid & + & + & + & + \\
Saponins & + & + & + & + \\
Cardiac glycoside & - & + & + & + \\
Tannins & - & - & + & + \\
Steroid & + & - & + & + \\
Triterpenes & + & + & + & + \\
Phenol & + & - & - & - \\
Anthraquinones & - & - & + & + \\
Carbohydrate & - & + & + & + \\
\hline
\end{tabular}

Table 3 showed that increase in concentration of extracts increased the zone of growth inhibition of the microorganism. The outcome of the antibacterial activity result indicated that $S$. aureus showed higher zone of inhibition $(24 \mathrm{~mm})$ followed by K. pneumoniae and $P$. aeruginosa with diameter zone of inhibition of $22 \mathrm{~mm}$ and $20 \mathrm{~mm}$ respectively at a concentration of $250 \mathrm{mg} / \mathrm{ml}$.

Table 3: Antibacterial activity of Citrullus lanatus leaf methanol extract

\begin{tabular}{|c|c|c|c|c|c|c|c|c|}
\hline \multirow{2}{*}{$\begin{array}{l}\text { Bacterial } \\
\text { isolates }\end{array}$} & \multicolumn{6}{|c|}{ Diameter Zone of Inhibition(mm) } & \multirow[t]{2}{*}{ MIC } & \multirow[t]{2}{*}{ MBC } \\
\hline & $250 \mathrm{mg} / \mathrm{ml}$ & $125 \mathrm{mg} / \mathrm{ml}$ & $62.5 \mathrm{mg} / \mathrm{ml}$ & $31.25 \mathrm{mg} / \mathrm{ml}$ & DMSO & AMC & & \\
\hline K. pneumoniae & 22 & 20 & 18 & 14 & 06 & 30 & 15.625 & 31.25 \\
\hline E. coli & 16 & 13 & 11 & 09 & 06 & 31 & 15.625 & 31.25 \\
\hline $\begin{array}{l}\text { Streptococcus } \\
\text { spp }\end{array}$ & 16 & 13 & 11 & 09 & 06 & 28 & 15.625 & 31.25 \\
\hline S. aureus & 24 & 20 & 15 & 13 & 06 & 34 & 15.625 & 31.25 \\
\hline P. aeruginosa & 20 & 17 & 13 & 11 & 06 & 30 & 15.625 & 31.25 \\
\hline
\end{tabular}

Key: $\mathrm{AMC}=$ amoxicillin/clavulanic acid, $\mathrm{DMSO}=$ Dimethyl sulphoxide

Table 4 showed that increase in concentration of extracts increased the zone of growth inhibition of the microorganism. The outcome of the antibacterial activity result indicated that $S$. aureus showed higher zone of inhibition $(20 \mathrm{~mm})$ followed by $K$. pneumoniae and $P$. aeruginosa $(18 \mathrm{~mm})$ each at a concentration of $250 \mathrm{mg} / \mathrm{ml}$. 
Table 4: Antibacterial activity of Citrullus lanatus Leaf Aqueous extract

\begin{tabular}{|c|c|c|c|c|c|c|c|c|}
\hline \multirow{2}{*}{$\begin{array}{l}\text { Bacterial } \\
\text { isolates }\end{array}$} & \multicolumn{6}{|c|}{ Diameter Zone of Inhibition(mm) } & \multirow[t]{2}{*}{ MIC } & \multirow[t]{2}{*}{ MBC } \\
\hline & $250 \mathrm{mg} / \mathrm{ml}$ & $125 \mathrm{mg} / \mathrm{ml}$ & $62.5 \mathrm{mg} / \mathrm{ml}$ & $31.25 \mathrm{mg} / \mathrm{ml}$ & DMSO & AMC & & \\
\hline К. pneumoniae & 18 & 14 & 13 & 12 & 06 & 30 & 15.625 & 31.25 \\
\hline E. coli & 15 & 12 & 11 & 09 & 06 & 31 & 15.625 & 31.25 \\
\hline $\begin{array}{l}\text { Streptococcus } \\
\text { spp }\end{array}$ & 14 & 13 & 11 & 09 & 06 & 28 & 15.625 & 31.25 \\
\hline S. aureus & 20 & 17 & 12 & 10 & 06 & 34 & 15.625 & 31.25 \\
\hline P. aeruginosa & 18 & 15 & 13 & 11 & 06 & 30 & 15.625 & 31.25 \\
\hline
\end{tabular}

Key: $\mathrm{AMC}=$ amoxicillin/clavulanic acid, DMSO= Dimethyl sulphoxide

From the results of the acute toxicity studies (Table 5), no death was recorded in the first phase. In the second phase, doses of 1,500, 2,250, 3,250 and 5,000 mg/ $\mathrm{kg}$ were used and no death was also recorded. The oral median lethal dose $\left(\mathrm{LD}_{50}\right)$ for the methanol leaf-extract of Citrullus lanatus was therefore estimated to be greater than $5000 \mathrm{mg} / \mathrm{kg}$ and no sign of behavioural changes were observed.

Table 5. Acute toxicity studies of aqueous and methanolic extracts of Citrullus lanatus Leaves

\begin{tabular}{|c|c|c|c|c|}
\hline Treatment & Group & Number of Animals & Dose $(\mathrm{mg} / \mathrm{kg})$ & $\begin{array}{c}\text { Mortality recorded } \\
\text { after } 24 \mathrm{hrs}\end{array}$ \\
\hline \multirow[t]{3}{*}{ Phase I } & I & 3 & 10 & $0 / 3$ \\
\hline & II & 3 & 100 & $0 / 3$ \\
\hline & III & 3 & 1000 & $0 / 3$ \\
\hline \multirow[t]{4}{*}{ Phase II } & $\mathrm{I}$ & 1 & 1500 & $0 / 1$ \\
\hline & II & 1 & 2250 & $0 / 1$ \\
\hline & III & 1 & 3250 & $0 / 1$ \\
\hline & IV & 1 & 5000 & $0 / 1$ \\
\hline
\end{tabular}

\section{DISCUSSION}

Chemo-microscopical examination of powdered leaves of Citrullus lanatus revealed the presence of cellulose, tannins, starch, lignin, calcium oxalate, suberin, aleurone grain and mucilage but calcium carbonate was absent (Table 1). It also revealed the presence of cellulose cell wall, lignified cell wall, tannins, starch, mucilage, calcium oxalate and cutin while calcium carbonate was absent. The microscopic structures are most valuable in the identification of powdered drug as their identification is largely based on the form, the presence or absence of certain cell types and cell inclusions (Jeremiah et al., 2019)

Many researchers have reported the presence of secondary metabolites in C. lanatus, which are generally found as components of plants (Ogungbamila and Samuelsson, 1990). The secondary metabolites reported by several researchers possessed appreciable inhibitory activities against various organisms (Cushine and Lamb, 2005). Phytochemical screening revealed the presence of phenolic compounds and flavonoids. These secondary metabolites might be responsible for the antibacterial activity of $C$. lanatus leaves, though they exert their antimicrobial activities through different mechanisms. Phenols are generally protoplasmic poisons toxic to all types of cells. Precipitation of proteins occurs with high concentration of phenol, while at low concentrations it denatures proteins without coagulating them. It freely penetrates the tissue because of its denaturing activity (Adeshina et al., 2012). Flavonoids on the other hand have been reported to be synthesized by plants in response to microbial infection, hence they exhibit antibacterial activities. The presence of flavonoids suggest that it can be used as an anti-spasmodic and antioxidant substance, and 
confirms the reason for the use of the plant in the treatment of spasmodic bronchitis and other microbial infections (Adeshina et al., 2012).

The diameter zones of inhibition, showed that the methanol extract had more activity than the aqueous extract. The degree of activity varied between the isolates and the extracts. This variation of activity could be due to the differences in the solubility of the secondary metabolite in the different solvents used, and also the structural or morphological variability of the tested isolates thus, larger zones of inhibition were produced by the susceptible organisms than the resistant ones. It could also be due to the polarity of the solvents, water been more polar dissolve more of the secondary metabolites (Adeshina et al., 2012). This result was different from that reported by Adeshina et al. (2012) which showed that the ethyl acetate fraction (non-polar solvent) of methanol extract of $A$. cordifolia leaf was relatively more active than the aqueous fraction (polar solvent) against isolates of E. coli, S. aureus, $P$. aeruginosa and Candida albicans. The observed differences may be as a result of variation of plant species, plants location and method of extraction. The result was similar to the findings of Mohammed et al. (2012) who reported that methanol extract exerted highest activity against $S$. aureus isolated from wound samples in Aminu Kano Teaching Hospital in Kano, Nigeria. The work of Gatsing et al. (2010) in Cameroon also showed that the aqueous leaf extract of $C$. lanatus was more active than the methanol and ethanol extracts against $E$. coli, P. aeruginosa, K. pneumoniae and $S$. aureus. The result did not corroborate report by Osumah et al. (2012) which revealed that the aqueous root extract of A. cordifolia had more activity than the methanol extract against E. coli, P. aeruginosa, S. aureus and S. typhi isolates from fecal material and wounds The diameter zones of inhibition showed a concentration dependent result and the result also showed that the zone of inhibition values of the extracts was far lesser than that of the positive control (amoxicillin/clavulanic acid). This may be attributed to the fact that conventional antibiotics are usually prepared from synthetic materials by means of reproducible manufacturing techniques and procedures, while herbal medicinal plants products are still crude, prepared from plant and animal origins and are subjected to contamination and deterioration most of the time (Mahmood and Ameh, 2007).

The M.I.C and M.B.C values were generally similar for the aqueous extract against the test isolates compared to those of the methanol extract. S. aureus was more susceptible to the extracts especially the methanol extract which showed lowest M.I.C and M.B.C values of $15.625 \mathrm{mg} / \mathrm{ml}$ and $31.25 \mathrm{mg} / \mathrm{ml}$ respectively. This is of great significance as it has been reported that this organism has developed resistance to many antibiotics, which sometimes makes its clinical management difficult (Adewunmi et al., 2001). This result corroborates the work of Osumah et al. (2012) who showed that the root and stem bark extracts and fractions of $C$. lanatus had more activity against $S$. aureus isolated from fecal and wound samples in Ahmadu Bello University Teaching Hospital Zaria. The differences in the susceptibilities of the isolates to the plant extracts can be related to the cell wall composition of the organisms. Gram - positive bacteria have their cell wall composed of peptidoglycan with techoic acid in between, making them more susceptible than the Gram - negative bacteria which have their cell wall surrounded by bi-lipid layers of Gram-negative lipopolysaccharides and lipoproteins, that prevent easy penetration of antibiotics through their cell wall.

The oral median lethal dose value for the aqueous and methanol leaf extracts of $C$. lanatus obtained in rats was found to be above $5000 \mathrm{mg} / \mathrm{kg}$ suggesting that the plant extract is nontoxic as no death was recorded. Acute toxicity studies are usually carried out to determine the dose that will cause death or serious toxic manifestations when administered singly or severally at few doses in order to establish doses that should be used in subsequent studies (Wanda et al., 2002). The Organization for Economic Cooperation and Development (OECD), recommended the chemical labelling and classification of acute systemic toxicity based on 
oral median lethal dose values as: very toxic if $\leq 5 \mathrm{mg} / \mathrm{kg}$, toxic if $>5 \mathrm{mg} / \mathrm{kg}$ but $\leq 50$ $\mathrm{mg} / \mathrm{kg}$, harmful if $>50 \mathrm{mg} / \mathrm{kg}$ but $\leq 500 \mathrm{mg} / \mathrm{kg}$, and non-toxic or not harmful if $>500$ $\mathrm{mg} / \mathrm{kg}$ or $\leq 2000 \mathrm{mg} / \mathrm{kg}$ (Walum, 1998). The $\mathrm{LD}_{50}$ was found to be greater than $5000 \mathrm{mg} / \mathrm{kg}$ when administered orally in rats (Table 5) and all the animals remained alive and did not manifest any significant visible signs of toxicity at these doses. This study showed that the extracts of $C$. lanatus leaves are practically non-toxic when administered using the oral route. This is based on the toxicity classification which states that substances with $\mathrm{LD}_{50}$ values of 5000 to $15,000 \mathrm{mg} / \mathrm{kg}$ body weight are practically non-toxic (Loomis and Hayes, 1996). The pharmacological activities of the drug may be attributed to the presence of secondary metabolites (Sharma et al., 2012). Hence, the presence of some metabolites in Citrullus lanatus suggests its activities against microbes.

\section{CONCLUSION}

From the above results, it can be concluded that the traditional medicinal plant $C$. lanatus is non-toxic, possesses diverse components in its leaves with antibacterial activity against the selected bacterial strains being more effective against $S$. aureus.

\section{REFERENCES}

Adeshina, G.O., Kunle, O. F.,Onaolapo, J.A., Ehinmidu J.O., Odama L.E. (2012) Antibacterial Activity of Aqueous and Ethyl Acetate sub-fractions of Alchornea cordifolia leaf. European Journal of Medicinal plants. 2 (1): 31-41.

Adesokan, A. A., Akanji, M. A. and Yakubu, M. T. (2007). Antibacterial potentials of aqueous extract of Enantia chlorantha stem bark. African Journal of Biotechnology, 6(22).

Adewunmi, C. O., Agbedahunsi, J. M., Adebajo, A. C., Aladesanmi, A. J., Murphy, N. and Wando, J. (2001). Ethno-veterinary medicine: Screening of Nigerian medicinal plants for trypanocidal properties. Journal of Ethnopharmacology. 77: 19-14.

Akanbi, M. O., Ukoli, C. O., Erhabor, G. E., Akanbi, F. O., Gordon, S. B. (2009). The burden of respiratory disease in Nigeria. The African Journal of Respiratory Medicine. 17.

Cheesbrough, M. (2006). Biochemical Test to Idenify Bacteria in Laboratory Practice in Tropical Countries. Cheesbrough M. (ed). Cambridge Edition 2: 63-87.

Cushine, T. P. T and Lamb, A. J. (2005). Antimicrobial activity of flavonoids. International Journal of Antimicrobial Agents. 26(5): 343-356.

Deshmukh, C. D., Jain, A. and Tambe, M. S. (2015). Phytochemical and Pharmacological profile of Citrullus lanatus (THUNB). Biolife, 3(2), 483-488.

Evans, W. C. (2009). Trease and Evans pharmacognosy, 16th edition, W. B. Saunders Ltd., London, $10-11$.

Furin, J., Gegia, M., Mitnick, C. (2011). Eliminating the category II retreatment regime from National tuberculosis progamme: The Georgian experience Bulletin of the World Health Organiztion. Article ID: BLT.11.092320.

Gatsing, D., Nkeugouap, F. N. C., Nji-Nkah, F. B., Kuiate, J. R., Tchouanguep, M. F. (2010). Antibacterial activity, bioavailability and acute toxicity evaluation of the leaf extracts of Alchornea cordifolia (Euphorbiaceae). International Journal of Pharmacology. 1811 7775.

Jafari, N. J., Ranjbar, R., Haghi-Ashtiani, M. T., Abedini, M., Izadi, M. (2009). The study of prevalence and antimicrobial susceptibility of tracheal bacterial strains isolated from paediatric patients. Pakistan Journal of Biomedical sciences. 12(5): 455-458.

Jeremiah, C., Katsayal, U.A., Nuhu, A., Nuhu, H.D. (2019). Pharmacognostic and Elemental Analysis of the Leaves of Tapinanthus globiferus (A. Rich). Tiegh. Res J Pharmacogn; 6(1): $11-18$. 
Karou, D., Savadogo, A., Canini, A., Yameogo, S., Montesano, C., Simoire, L., Colizzi, V., Traore, A.S. (2006). Antibacterial activity of alkaloids from Sida acuta. African Journal of Biotechnology. 5(2): 195-200.

Loomis, T.A and Hayes, A.W.(1996). Loomis Essentials of Toxicology. (4th ed.). California, U.SA: Academic Press; 208- 245 p.

Lorke, D. (1983). A New Approach to Practical Acute Toxicity Testing. Archives of Toxicology. Pp. 275-287.

Mahmood, A., Ameh, J. M. (2007). In-vitro antibacterial activity of Parkia biglobosa (Jacq) root, bark extract against some microorganisms associated with Urinary tract infections. African Journal of Biotechnology. 6, 195-200.

Mohammed, A., Adeshina, G. O., Ibrahim, Y. K. E. (2012). Incidence of wound infections in a teaching hospital in Kano and susceptibility of the bacteria isolates to Alchornea cordifolia leaf extracts. M.sc Research Dissertation (Unpublished).Department of Pharmaceutics/ Pharmaceutical Microbiology Library. Ahmadu Bello University, Zaria.

National Committee for Clinical Laboratory Standards (2008).Performance Standards for Antimicrobial Susceptability Testing ; Ninth Informational Supplement. NCCLS document M100-S9. National Committee for Clinical Laboratory Standards, Wayne, PA.

Ogungbamila, F.O. and Samuelsson, G. (1990): Smooth Muscle Relaxing Flavonoids from Alchornea cordifolia. Acta, Pharma Nordica 2 (6): 421-422.

Osumah, R. O., Adeshina, G. O., Ehinmidu, J. O. (2012). Phytochemical and antibacterial studies of the stem bark and root of Alchornea cordifolia (Euphorbiaceae). M.sc Research Dissertation (Unpublished).Department of Pharmaceutics/ Pharmaceutical Microbiology Library. Ahmadu Bello University, Zaria. Pp: 58-66.

Rojas, J.J., Ochoa, V.J., Ocampo, S.A., Munoz, J.F. (2006). Screening for antimicrobial activity of ten medicinal plants used in Colombian folkloric medicine: A possible alternative in the treatment of non-nosocomial infections. BMC Complement. Alternative Medicine, 6:2.

Srinivasan, L., Sasaki, Y., Calado, D.P., Zhang, B., Paik, J.H., DePinho, R.A., Kutok, J.L., Kearney, J.F., Otipoby, K.L. and Rajewsky, K. (2009). PI3 kinase signals BCRdependent mature B cell survival. Cell, 139:573-586.

Sylvester, N.M. (2016). Phytochemical and Antivenom activity of Albizia chivelieri stem bark on Naja nigricollis Broadley Envenomated Mice. M.sc Research Dissertation (Unpublished).Department of Pharmacognosy and Drug Development Library. Ahmadu Bello University, Zaria. Pp: 47-48.

Walum, E. (1998). Acute oral toxicity. Environmental Health Perspective, 106, 497-503.

Wanda M.H., Colin G.R., and Mathew A.W. (2002). Handbook of toxicologic pathology, 2ndEdition, Academic Press.

World Health Organization (2011). Quality Control Methods for Medicinal Plants. WHO, Geneva, Switzerland, Pp. 31.

Zafar, A., Hussain, Z., Lomama, E., Sibliie, S., Irfan, S., Khan, E. (2008). Antibiotic susceptibility of pathogens isolated from patients with community-acquired respiratory tract infections in Pakistan- the active study. Journal of Ayub Medical College, Abbottabad. 20: 7-9. 